\title{
DESTRUCTIVE WAVE OVERTOPPING TESTS ON FLEMISH DIKES
}

\author{
Gosse Jan Steendam ${ }^{1}$, Patrik Peeters ${ }^{2}$, Jentsje van der Meer $^{3}$, Koen van \\ Doorslaer $^{4}$ and Koen Trouw ${ }^{5}$
}

Breaching of dikes induced by wave overtopping is one of the main failure mechanisms causing coastal floods. But also at (estuarine) river dikes overtopping may occur. In order to increase knowledge on this mechanism, the performances of grass cover layers and the parameters involved, research is performed with the Wave Overtopping Simulator. Following field tests in The Netherlands, this knowledge was expanded by tests performed in Flanders (Belgium) at a controlled inundation area at Tielrode near Antwerp.

\section{INTRODUCTION}

\section{Actualised Sigmaplan and Integrated Coastal Safety Plan}

Due to changing physical circumstances and new insights in water management, recently an actualisation of the Sigmaplan (safety plan for the tidal river Schelde) was elaborated. The so-called Actualised Sigmaplan aims for satisfying safety and ecological needs along the river Schelde in a sustainable way. Therefore different restoration techniques are elaborated which combine safety

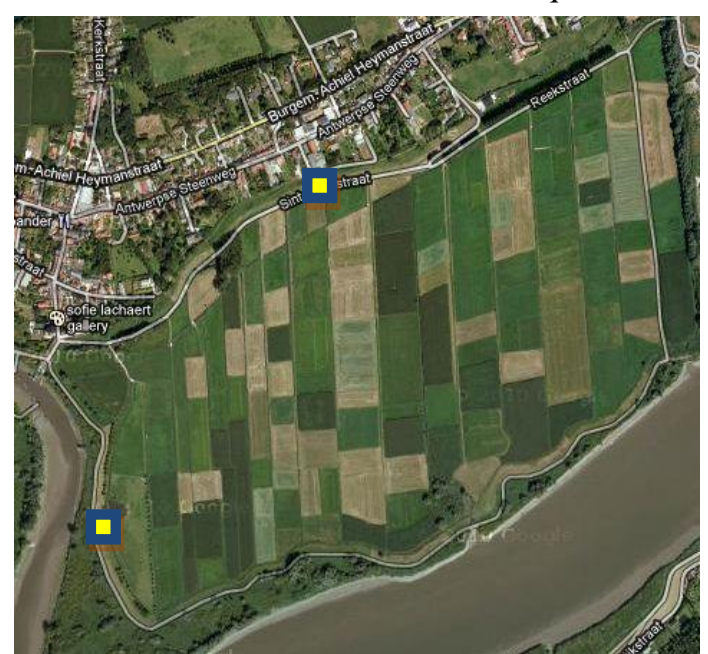

Figure 1. Location of the Wave Overtopping tests with estuarine restoration, eg. dike strengthening together with more space for the river, flood control areas with or without a controlled reduced tide and non-tidal wetlands .

Also for the coastal areas a large scale safety plan is available. According to this plan, the safety level of one third of the Belgian coastline needs to be increased to withstand extreme storm floods, providing a minimum safety standard of once in 1000 years (Mertens et al., 2010). Storm walls are to be

${ }_{1}^{1}$ INFRAM b.v., PO Box 16, 8316 ZG Marknesse, Netherlands, gosse.jan.steendam@infram.nl

${ }^{2}$ Flanders Hydraulics Research, Berchemlei 115, B-2140, Antwerp, Belgium, patrik.peeters@mow.vlaanderen.be

${ }^{3}$ Van der Meer Consulting, P.O. Box 423, 8440 AK Heerenveen, Netherlands, jm@vandermeerconsulting.nl

${ }_{4}$ Ghent University, Technologiepark 904, B-9052 Zwijnaarde, Belgium, koen.vandoorslaer@ugent.be

${ }^{5}$ Authority of Flanders, Ministry of Transport and Public Works, Coastal Division, Vrijhavenstraat 3, 8400 Oostende, Belgium, koen.trouw@mow.vlaanderen.be 
built at several locations, such as harbours and seaward protruded areas. Structural strengthening of these storm walls is needed in order to resist the impact of waves during extreme events. However, no theoretical formulae exist to estimate the impact forces of overtopping waves on a vertical wall.

\section{WAVE OVERTOPPING TESTS}

The river Schelde stretches from the Dutch-Belgian border all the way to the city of Gent. To manage peak water levels during storm surges flood control area's (FCA) are constructed along the tidal reach of the river. During storm surges, the FCA is filled via a lowered dike section. A ring dike prevents uncontrolled flooding outside the flood control area.

Ring dikes are constructed with various materials as are the dike cover layers. Also the maintenance and management of these dikes can differ from one place to another. To get a sound impression on how the Sigma dikes and ring dikes behave at conditions with waves overtopping the dikes, prototype tests with the Wave Overtopping Simulator were conducted at two locations (see figure 1). Previous experiences in The Netherlands with prototype and destructive tests with the Wave Overtopping Simulator are described in Steendam et al., 2008, Steendam et al., 2010 and Van der Meer et al., 2009. The purpose of the present investigation was to explore the sensitivity of dikes for breaching caused by overtopping waves and more specific, the strength of the grass cover and underlying top layer. The tests were performed in December 2010. With the Wave Overtopping Simulator the effect of an extreme storm can be simulated, resulting in a large number of waves overtopping the dike with overtopping volumes ranging from 100 to 5,5001 per $\mathrm{m}$. Here, in each test an average overtopping discharge, expressed in 1/s per m, ranging from 1 up to $50 \mathrm{l} / \mathrm{s}$ per m, was released in individual overtopping waves. These quantities are far larger than the design conditions. A total of 4 sections have been tested:

1. Sigma dike with slope angle 1:4 (with and without man made damage);

2. Ring dike with slope angle 1:2.5 with high fine sand content and rugged vegetation;

3. Ring dike with slope angle 1:2.5 with rugged vegetation;

4. Ring dike with high hydraulic loads (larger significant wave height with the same mean overtopping discharge as the other tests).

Each of the tested sections had different characteristics in terms of vegetation types and appearance of grass cover, management status and composition (a more sandy versus clayey content) of cover layer. All of these characteristics have been investigated.

The first section was a Sigma dike with a tested landward slope of 1:4. Before testing the grass cover was investigated in detail. Overall conclusion of this investigation was that this particular section showed no large irregularities. At the transition of the asphalt road on the crest of the dike towards the grass covered slope some minor damage was present. Across the slope some small bold spots were found, in the order of $0.1 \times 0.1 \mathrm{~m}$. At the berm of the test section a walnut tree was present with a stem diameter of around $0.75 \mathrm{~m}$. The vegetation 
on the slope showed a reasonable good grass cover with some Stinging Netlles and Thistles.

At sections 2, 3 and 4 the slope angle was steeper, 1:2.5. The surface of the slope was irregular. Also some (sheep) trails were present. The vegetation was rugged and showed a lot of stinging nettle and thistles.

\section{TEST CONDITIONS}

The test condition for sections 1 to 3 were set assuming a significant wave height of $\mathrm{H}_{\mathrm{s}}=0.75 \mathrm{~m}$ for wave overtopping conditions with a mean overtopping discharge up to $20 \mathrm{l} / \mathrm{s}$ per $\mathrm{m}$. For larger mean overtopping discharges $\mathrm{H}_{\mathrm{s}}=1.0 \mathrm{~m}$ was taken. At this river location at extreme conditions the wave are expected to be steep wind waves with a wave steepness of about 0.05 . Therefore this is taken to calculate the wave period. Table 1 shows the test conditions. The duration of the tests was set to 2 hours, corresponding to the expected peak of the local high water situation (tidal). Section 4 was tested outside the test program for these particular river conditions. To increase knowledge within the Dutch program of Strengths and Loads on dikes (SBW) regarding the method of cumulative overload (Van der Meer et al., 2010), much higher wave conditions were simulated $\left(\mathrm{H}_{\mathrm{s}}=3 \mathrm{~m}\right)$ on an additional dike section. Table 1 gives an overall view of all relevant parameters.

\begin{tabular}{|c|c|c|c|c|c|c|c|c|c|}
\hline \multicolumn{10}{|c|}{ Table 1 Test conditions } \\
\hline Test section & $\begin{array}{c}\mathrm{t} \\
\text { (hours) }\end{array}$ & $\begin{array}{c}q \\
(1 / s \text { per m) }\end{array}$ & $\begin{array}{l}\mathrm{H}_{\mathrm{s}} \\
(\mathrm{m})\end{array}$ & $\begin{array}{l}T_{p} \\
(\mathrm{~s})\end{array}$ & $\begin{array}{c}T_{\mathrm{m} 0,-1} \\
(\mathrm{~s})\end{array}$ & $\begin{array}{l}\mathrm{T}_{\mathrm{m}} \\
(\mathrm{s})\end{array}$ & $\begin{array}{l}R_{c} \\
(m)\end{array}$ & $\begin{array}{l}\begin{array}{l}P_{o v} \\
(\%)\end{array} \\
\end{array}$ & $\begin{array}{l}\text { Nov } \\
(-)\end{array}$ \\
\hline $1,2,3$ & 2 & 1 & 0.75 & 3.1 & 2.8 & 2.5 & 1.36 & 10.2 & 295 \\
\hline $1,2,3$ & 2 & 10 & 0.75 & 3.1 & 2.8 & 2.5 & 0.82 & 43.5 & 1264 \\
\hline $1,2,3$ & 2 & 30 & 1.0 & 3.6 & 3.3 & 2.9 & 0.89 & 58.0 & 1450 \\
\hline $1,2,3$ & 2 & 50 & 1.0 & 3.6 & 3.3 & 2.9 & 0.73 & 69.3 & 1733 \\
\hline 4 & 2 & 1 & 3.0 & 6.2 & 5.6 & 5.0 & 7.42 & 1.4 & 20 \\
\hline 4 & 2 & 5 & 3.0 & 6.2 & 5.6 & 5.0 & 5.90 & 6.8 & 98 \\
\hline 4 & 3 & 10 & 3.0 & 6.2 & 5.6 & 5.0 & 5.24 & 12.0 & 259 \\
\hline
\end{tabular}

\section{RESULTS}

At the first section after completing all test conditions, no damage was found. Only superficial erosion of the grass cover had taken place. No damage was found near the tree at the berm. Minor damage occurred at the transition from the asphalt road to the grass covered slope. Next, pre defined superficial damages were applied to the slope. At 6 locations along the slope ranging from $0,15 \times 0,15 \mathrm{~m}$ to $0,35 \times 0,35 \mathrm{~m}$, the sward and turf part of the vegetation was removed. The rooted part of the topsoil was left in place. After completing again the total test conditions, damage only had grown little. 


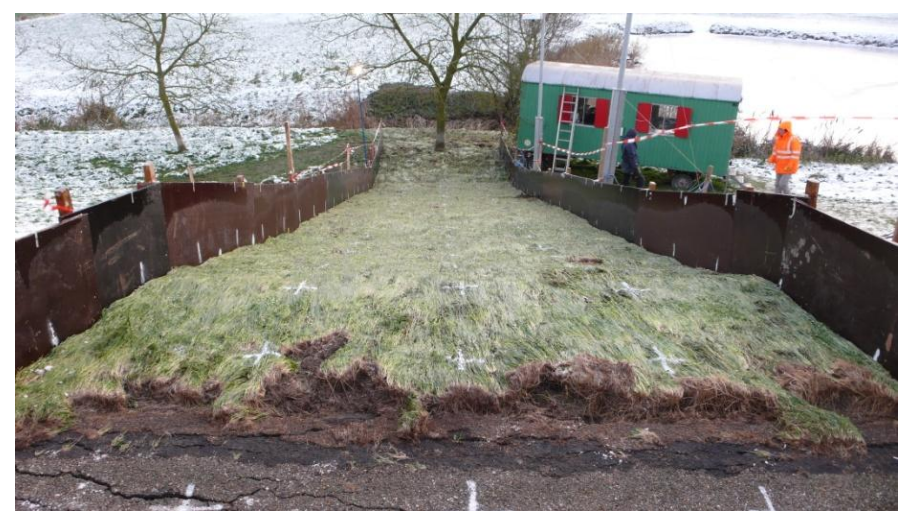

Figure 3. Final result test section 1, looking down the slope; minor damage at transition asphalt road to grass covered slope 1:4.

At the second test section (slope 1:2.5; high fine sand content) the initially irregular slope damaged quickly and failed after 36 minutes of $30 \mathrm{l} / \mathrm{s}$ per $\mathrm{m}$ (see figure 4).

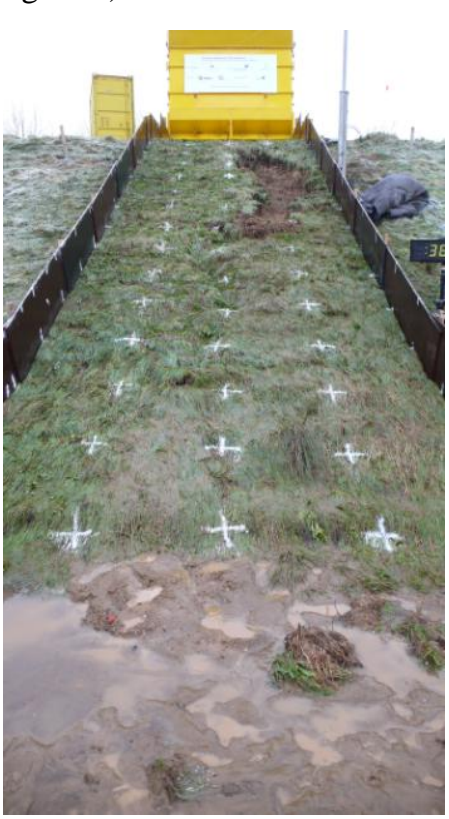

Figure 4. End result of section 2.

Also the third test section failed at a mean discharge of $30 \mathrm{l} / \mathrm{s}$ per $\mathrm{m}$. This time the failure happened after 21 minutes (see figure 5). After provisionally repairing the damage with sand bags and covering it up with a fixed geotextile, the test was continued for an extra 10 minutes. In addition, to assess the stability of the sand bags alone, the geotextile was removed and 10 minutes of testing were done on uncovered sand bags.

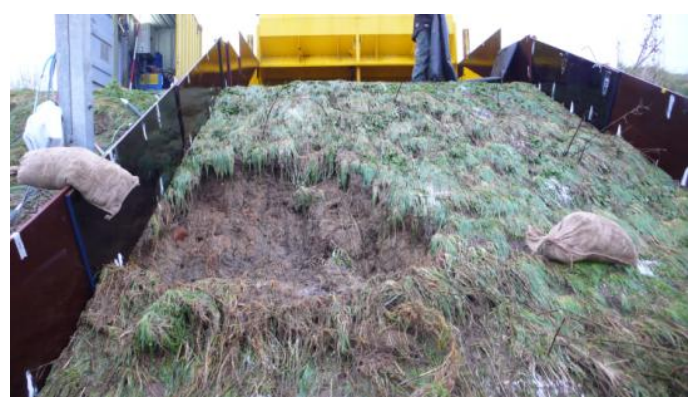

The fourth section was performed with high hydraulic conditions $\left(\mathrm{H}_{\mathrm{s}}=3 \mathrm{~m}\right)$. From experience on sections 2 and 3 and the assumption that large overtopping waves which exceed a certain critical volume or velocity cause damage, it was expected that this section would fail at $10 \mathrm{l} / \mathrm{s}$ per $\mathrm{m}$. But after 2 hours of $10 \mathrm{l} / \mathrm{s}$ 
per $m$ the expectations were not met. It then was decided to go on testing with the same conditions. After one more hour the slope indeed failed (see figure 6).

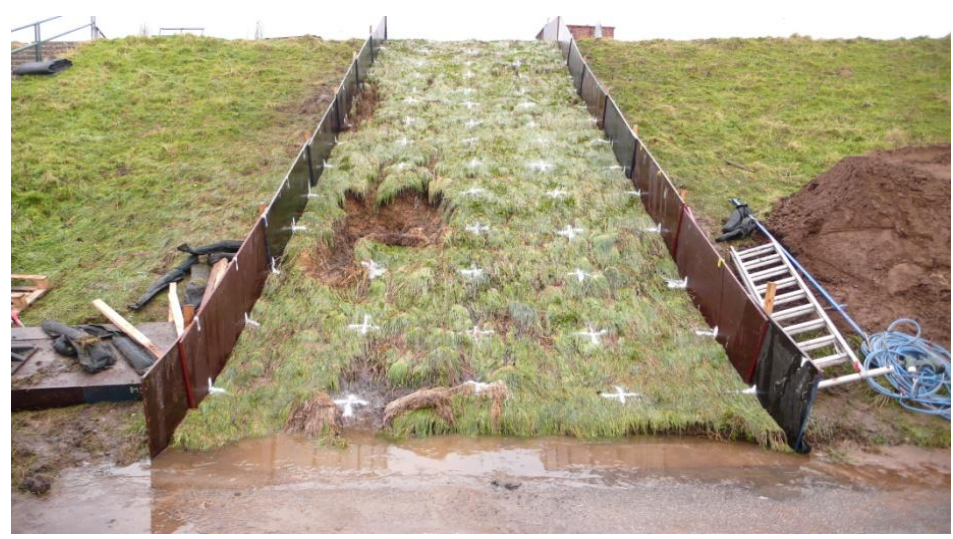

Figure 6. Failure of section 4.

Table 2 shows all tests performed together with some damage indicators.

\begin{tabular}{|c|c|c|c|c|}
\hline Section & Location & $\begin{array}{l}\text { Test (I/s per } \\
\text { m) }\end{array}$ & $\begin{array}{l}\begin{array}{l}\text { Duration } \\
\text { (hours) }\end{array} \\
\text { (hours }\end{array}$ & Damage \\
\hline \multirow[t]{8}{*}{1} & \multirow[t]{8}{*}{ Sigmadike } & 1 & 2 & (5 times faster) no damage \\
\hline & & 10 & 2 & No damage \\
\hline & & 30 & 2 & No damage \\
\hline & & 50 & 2 & No damage \\
\hline & & 1 & 2 & Damage was self inflicted before testing \\
\hline & & 10 & 2 & No increase in damage \\
\hline & & 30 & 2 & No increase in damage \\
\hline & & 50 & 2 & No increase in damage \\
\hline \multirow[t]{3}{*}{2} & \multirow[t]{3}{*}{ Ring dike } & 1 & 2 & (5 times faster) no damage \\
\hline & & 10 & 2 & Minor evolving erosion spots \\
\hline & & 30 & $38 / 60$ & Slope failed \\
\hline \multirow[t]{3}{*}{3} & \multirow[t]{3}{*}{ Ring dike } & 1 & 2 & (5 times faster) \\
\hline & & 10 & 2 & No damage \\
\hline & & 30 & $20 / 60$ & Slope failed \\
\hline \multirow[t]{3}{*}{4} & \multirow[t]{3}{*}{ Ring dike } & 1 & 2 & (5 times faster) no damage \\
\hline & & 5 & 2 & Minor evolving erosion spots \\
\hline & & 10 & 3 & Slope failed \\
\hline
\end{tabular}

\section{ANALYSIS}

\section{Distribution of Overtopping Wave Volumes}

Overtopping waves vary in volume depending on a lot of factors. Most important is the incident wave. Irregular waves cause irregular wave run up and if the structure is not high enough, irregular overtopping volumes. In the 
EurOtop Manual, 2007, the wave overtopping discharges at all kind of coastal structures are well described, including the distribution of overtopping wave volumes. The overtopping discharge, $\mathrm{q}$, is the total volume of overtopped water (per unit length) in a certain time span, divided by this time span. The distribution is characterized by many small overtopping waves and a few much larger ones and can be described by:

$$
\begin{gathered}
P_{V}=P(\underline{V} \leq V)=1-\exp \left[-\left\{\frac{\mathrm{v}}{\mathrm{a}}\right\}^{0.75}\right] \\
a=0.84 \cdot T_{m} \cdot q \cdot \frac{N_{w}}{N_{o w}}=0.84 \cdot q \cdot \frac{t}{N_{o w}}
\end{gathered}
$$

$\mathrm{P}_{\mathrm{V}}=$ probability of the overtopping volume $\underline{\mathrm{V}}$ being smaller than $\mathrm{V}$

$\mathrm{V}=$ overtopping wave volume $\left(\mathrm{m}^{3} / \mathrm{m}\right)$

$\mathrm{T}_{\mathrm{m}}=$ mean wave period $(\mathrm{s})$

$\mathrm{q}=$ mean overtopping discharge $\left(\mathrm{m}^{3} / \mathrm{s}\right.$ per $\mathrm{m}$ width $)$

$\mathrm{N}_{\mathrm{w}}=$ number of incident waves

$\mathrm{N}_{\text {ow }}=$ number of overtopping waves

$\mathrm{t}=$ duration of test or storm $(\mathrm{s})$

The overtopping wave volumes in reality occur randomly in time. Figure 7 shows the distributions of the test conditions for sections 1 to 3 and separately 4 which were randomly simulated by the Wave Overtopping Simulator.
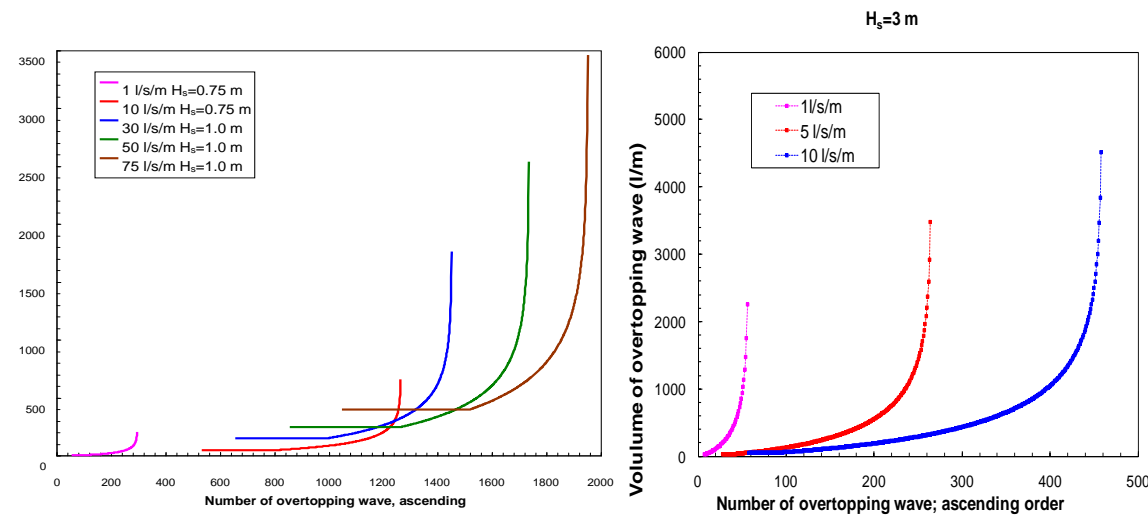

Figure 7. Distributions of simulated overtopping wave volumes

In Van der Meer et al., 2010 an empirical relation is derived between overtopping velocities on the landward slope and overtopping volumes. This relation is given in (Eq. 3).

$$
u=5.0 V^{0.34}
$$

$\mathrm{u}=$ velocity of overtopping wave at landward slope $(\mathrm{m} / \mathrm{s})$

$\mathrm{V}=$ overtopping wave volume $\left(\mathrm{m}^{3} / \mathrm{m}\right)$ 
It was also found that for velocities up to $3 \mathrm{~m} / \mathrm{s}$ (wave overtopping volumes up to $500 \mathrm{l} / \mathrm{m}$ ) there is no difference between velocity at ground level and the top of the flow. There is hardly a boundary layer present and the measured velocities can be considered as the depth-averaged velocities. For larger velocities and overtopping wave volumes it was clear that the velocity at ground level is smaller than at the top of the flow. Maximum velocities at ground level (first $\mathrm{cm}$ ) are about $5 \mathrm{~m} / \mathrm{s}$ and at the top of the flow about $9 \mathrm{~m} / \mathrm{s}$.

\section{Cumulative Hydraulic Overload}

In Van der Meer et al., 2010 it was found that a mean wave overtopping discharge does not describe the full story of wave overtopping. Larger wave conditions leading to a certain mean discharge cause more damage on landward slopes as lower wave heights (more waves with less volume, leading to the same mean overtopping discharge).

From earlier tests in the Netherlands it became clear that it is not that straightforward to predict when a grassed or vegetated slope will start to encounter damage and/or experiences failure. In Van der Meer et al., 2010 it was suggested that failure is defined: the sand core underneath the soil layer becomes free and damage develops fast. Next, the "Start of damage" would be defined as "Various damaged locations". This also implies that it does not depend solely on one weak spot. First damage was not described, but the figure in the paper suggests first damage to be a first clearly evolving erosion spot. In the case the grassed slope does not fail, the condition "no failure" also is a criterion. In summary the following damage criteria were found:

- Non-failure after testing (damage too small to call damage)

- First damage (evolving superficial erosion spots or single damaged spot)

- Various damaged locations

- Failure (ongoing damage reaching the core of the dike)

In all cases the velocity of the overtopping wave plays a role and a critical velocity, which should be exceeded before erosion will take place. For the tests in Flanders an analysis has been made in accordance with Van der Meer et al., 2010 , in which the development of a new wave overtopping criterion is shown, the Cumulative Hydraulic Overload.

The method is partly based on excess of shear stress, but time of flow is not included was is defined by:

$$
\mathrm{CHO}=\Sigma\left(\mathrm{u}^{2}-\mathrm{u}_{\mathrm{c}}^{2}\right) \quad\left[\mathrm{m}^{2} / \mathrm{s}^{2}\right]
$$

With known distributions of overtopping wave volumes (Eqs. 1 and 2) and known velocities per overtopping wave volume (Eq. 3 ) it is possible to calculate the cumulative hydraulic overload for each wave overtopping condition, or a number of tests, at a certain moment when a damage criterion is reached. However, the cumulative hydraulic overload depends also on the critical velocity $u_{c}$ that is assumed. The main question is now: what is the critical velocity, $u_{c}$, that integrates the observed damages for different hydraulic 
regimes? The four damage criteria were taken for all tests and the results were compared for critical velocities of $0 ; 3.1 ; 4.0 ; 5.0$ and $6.3 \mathrm{~m} / \mathrm{s}$, which are in accordance with overtopping wave volumes of $0 ; 0.25 ; 0.5 ; 1$ and $2 \mathrm{~m}^{3} / \mathrm{m}$.

Table 3 is the same table as table 2 but with the extension of cumulative overloads $\left(\mathrm{m}^{2} / \mathrm{s}^{2}\right)$, defined in (4) and damages in pre-defined classifications.

\begin{tabular}{|c|c|c|c|c|c|c|c|c|}
\hline \multirow[t]{2}{*}{ Section } & \multirow{2}{*}{$\begin{array}{l}\text { Test } \\
(\mathrm{l} / \mathrm{s} \text { per m) }\end{array}$} & \multirow{2}{*}{$\begin{array}{l}\text { Duration } \\
\text { (hours) }\end{array}$} & \multirow[t]{2}{*}{ Damage } & \multicolumn{5}{|c|}{ Critical velocity $(\mathrm{m} / \mathrm{s})$} \\
\hline & & & & 0 & 3,1 & 4,0 & 5,0 & 6,3 \\
\hline \multirow[t]{11}{*}{1} & 1 & 2 & Non-failure & 460 & 0 & 0 & 0 & 0 \\
\hline & 10 & 2 & Non-failure & 3604 & 94 & 5 & 0 & 0 \\
\hline & 30 & 2 & Non-failure & 7860 & 1352 & 405 & 49 & 0 \\
\hline & 50 & 2 & Non-failure & 11558 & 2997 & 1175 & 240 & 11 \\
\hline & & & cumulative & 23482 & 4442 & 1585 & 289 & 11 \\
\hline & 1 & 2 & Non-failure & 460 & 0 & 0 & 0 & 0 \\
\hline & 10 & 2 & Non-failure & 3604 & 94 & 5 & 0 & 0 \\
\hline & 30 & 2 & Non-failure & 7860 & 1352 & 405 & 49 & 0 \\
\hline & 50 & 2 & Non-failure & 11558 & 2997 & 1175 & 240 & 11 \\
\hline & & & cumulative & 23482 & 4442 & 1585 & 289 & 11 \\
\hline & & & Total section 1 & 46964 & 8885 & 3171 & 578 & 22 \\
\hline \multirow[t]{4}{*}{2} & 1 & 2 & Non-failure & 460 & 0 & 0 & 0 & 0 \\
\hline & 10 & 2 & First damage & 3604 & 94 & 5 & 0 & 0 \\
\hline & 30 & $38 / 60$ & Failure & 2543 & 386 & 103 & 12 & 0 \\
\hline & & & cumulative & 6607 & 480 & 108 & 12 & 0 \\
\hline \multirow[t]{4}{*}{3} & 1 & 2 & Non-failure & 460 & 0 & 0 & 0 & 0 \\
\hline & 10 & 2 & Non-failure & 3604 & 94 & 5 & 0 & 0 \\
\hline & 30 & $20 / 60$ & Failure & 1354 & 194 & 40 & 1 & 0 \\
\hline & & & cumulative & 5418 & 288 & 46 & 1 & 0 \\
\hline \multirow[t]{5}{*}{4} & 1 & 2 & Non-failure & 201 & 89 & 55 & 19 & 0 \\
\hline & 5 & 2 & First damage & 944 & 464 & 276 & 120 & 30 \\
\hline & 10 & 2 & $\begin{array}{l}\text { Various damaged } \\
\text { locations }\end{array}$ & 1984 & 858 & 492 & 207 & 41 \\
\hline & 10 & 1 & Failure & 912 & 457 & 292 & 140 & 61 \\
\hline & & & cumulative & 4040 & 1868 & 1116 & 485 & 132 \\
\hline
\end{tabular}

From experience in previous tests in the Netherlands it was concluded that the following indicators could be used as damage criteria, where actually the failure criterion is the most reliable. Small or first damage shows a lot of scatter:
First damage:
$\Sigma\left(\mathrm{u}^{2}-\mathrm{u}_{\mathrm{c}}^{2}\right)=500 \mathrm{~m}^{2} / \mathrm{s}^{2}$
Various damaged locations: $\quad \Sigma\left(\mathrm{u}^{2}-\mathrm{u}_{\mathrm{c}}^{2}\right)=1000 \mathrm{~m}^{2} / \mathrm{s}^{2}$
Failure:
$\Sigma\left(\mathrm{u}^{2}-\mathrm{u}_{\mathrm{c}}^{2}\right)=3500 \mathrm{~m}^{2} / \mathrm{s}^{2}$

For section 1 it can be concluded that the slope did not show damage at all, not even after repeating the tests after inflicting man made damages. Therefore the criteria imply that the critical velocity $\mathrm{u}_{\mathrm{c}}$ on test section 1 must be fairly high.

For section 2 and 3 the situation is completely different. Both slopes failed after less than 40 minutes of $30 \mathrm{l} / \mathrm{s}$ per $\mathrm{m}$. From table 3 and the damage criteria it may be concluded that the critical velocity must be less than $3.1 \mathrm{~m} / \mathrm{s}$. If the critical 
velocity would be $3.1 \mathrm{~m} / \mathrm{s}$ one would only expect First damage and not Failure of the slope.

At section 4 the slope failed after 3 hours of $10 \mathrm{l} / \mathrm{s}$ per $\mathrm{m}$ but with a larger hydraulic load $\left(\mathrm{H}_{\mathrm{s}}=3 \mathrm{~m}\right)$. Looking at table 3 and the damage criteria again it can be concluded that the critical velocity of the tested slope is below $3.1 \mathrm{~m} / \mathrm{s}$ $\left(\mathrm{V}<0,25 \mathrm{~m}^{3} / \mathrm{m}\right)$.

The behaviour of the tested slope on the Sigma dike was good. The behaviour of the tested slopes on the Ring dike on the other hand was poor related to the findings in previous tests in the Netherlands. Investigations have been made on grass cover and soil type. From analysis of this information it may become clear what caused this behaviour. But beforehand it is known that the slope angle of the sections on the Ring dike were much steeper (1:2.5) than those of the Sigmadike (1:4). Also by visual inspection, the grass cover seemed in a not so good condition. It was also known that the material used to construct the dike was mainly silty sand with some clay. Probably the measured characteristics of the soil will show low strength against erosion. The combination of this low resistance against erosion, high permeability as well as the poor shape of grass cover and the steepness of the slope resulted in a low resistance against hydraulic loads due to overtopping waves.

\section{FORCES ON VERTICAL WALLS}

The Belgium Integrated Master Plan for Coastal Safety has been developed to protect the coast sufficiently against severe storm events (Mertens et al., 2008). Weak spots have been determined, and safety measures are proposed, based on an intense campaign of numerical and experimental research. One of these measures are storm walls located at 10 to $15 \mathrm{~m}$ behind the crest of a dike (along the coastline) or quay wall (in harbours). These walls are designed to withstand wave impacts and are therefore subject to very high forces. The magnitude of these forces and force-over-time signal will determine the foundation, rebar and dimensions of the walls. But also a lot of buildings exist on top of the sea wall and overtopping waves could hit walls of such buildings. 

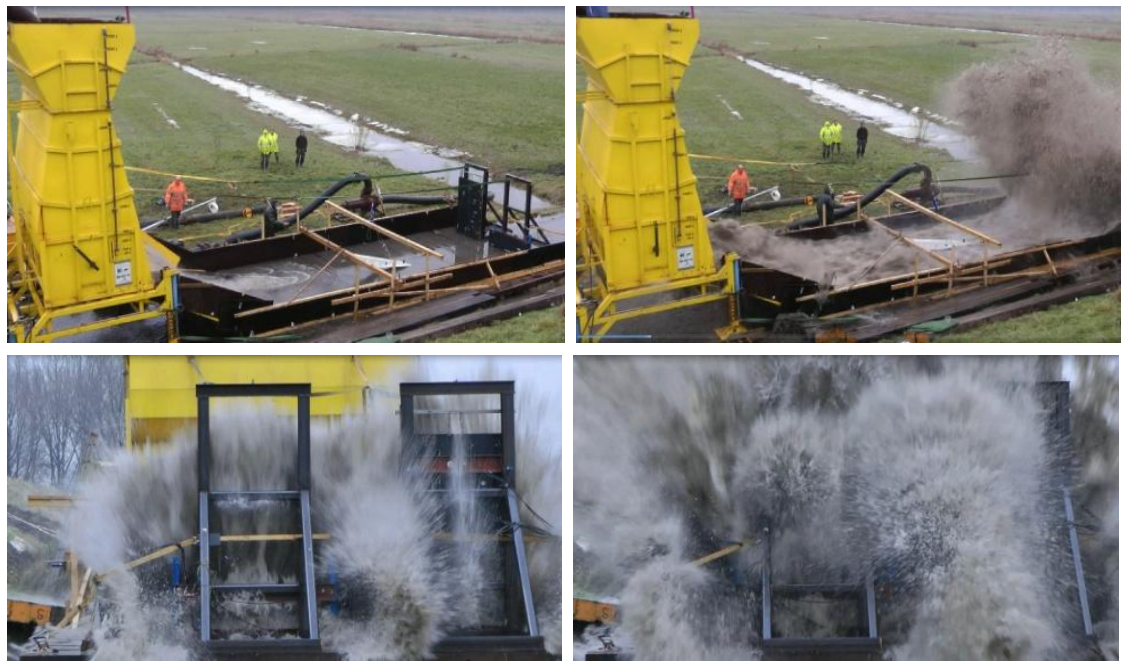

Figure 8. Impression of wave force measurements

Up till now, there are no theoretical formulae which allow design engineers to estimate these wave forces on a storm wall due to overtopping waves. The Wave Overtopping Simulator is therefore used to simulate an overtopping wave which impacts a storm wall located at $10 \mathrm{~m}$ behind the crest (Figure 8 ). Two aluminium plates acted as storm walls: one vertical $(1.7 \mathrm{~m}$ high $\mathrm{x} 0.5 \mathrm{~m}$ wide) and one horizontal $(0.5 \mathrm{~m}$ high $\times 1.7 \mathrm{~m}$ wide $)$. Each plate was equipped with 4 force sensors, one in every corner of the plate. The force signals of the 4 sensors in the vertical plate are shown in figure 9.

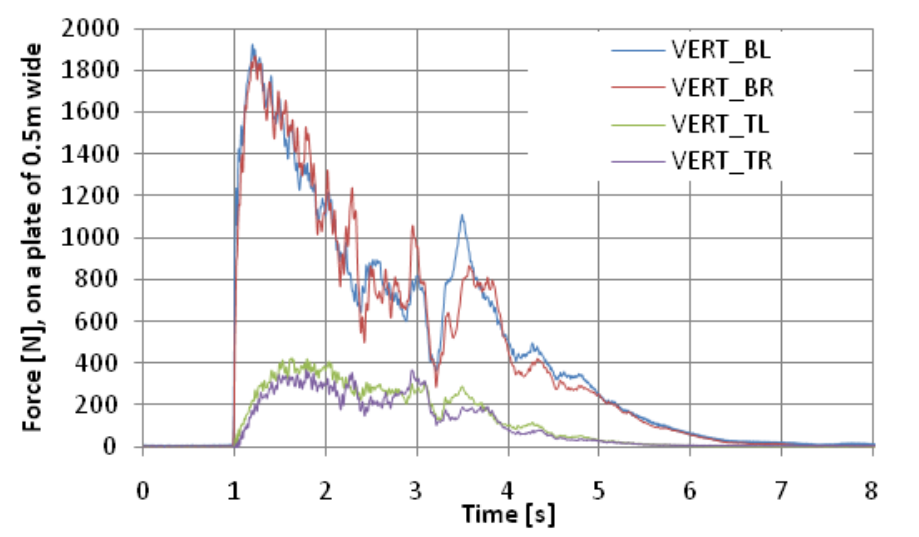

Figure 9. Force signal over time on a vertical plate, for a wave of $3500 \mathrm{l} / \mathrm{m}$

The force signal of a bottom sensor (red/blue) shows a very steep rise over time, and reaches much higher values than the top sensors (purple/green). The flow 
depth, located near the bottom sensor, is a governing parameter for the force distribution over height.

In figure 10 , the maximum forces per meter width on the horizontal plate $(0.5 \mathrm{~m}$ high) and the vertical plate $(1.7 \mathrm{~m}$ high) are plotted versus the overtopping volume. There is a very clear trend between both, with a correlation of about $99 \%$.

Horizontal plate: $\quad F=2.24 \mathrm{~V}$

Vertical plate: $\quad F=0.13 V^{2}+2.22 \mathrm{~V}$

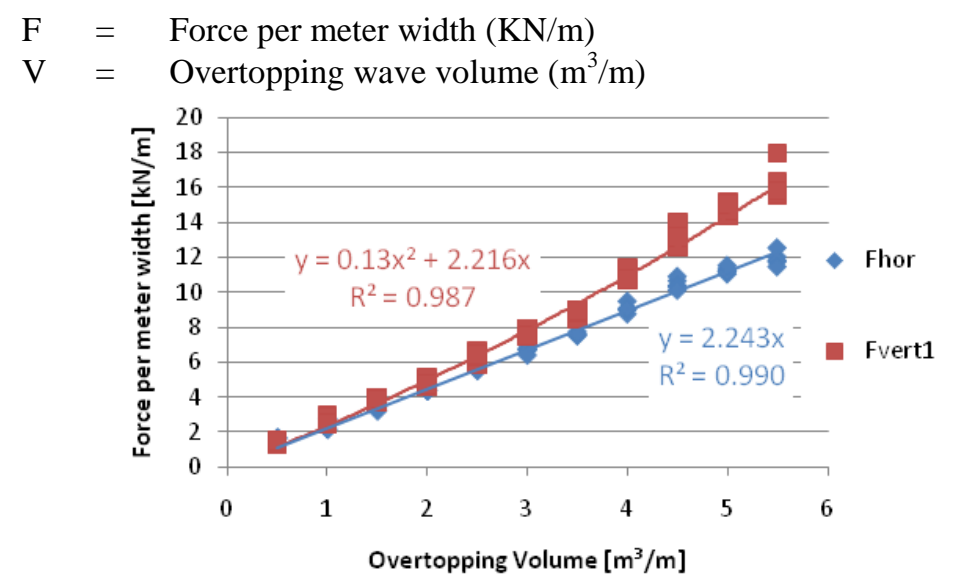

Figure 10. Force as a function of volume. Horizontal plate blue, vertical red.

The difference between horizontal and vertical plate is rather small, despite the vertical plate being 3 times higher. The flow depth is a governing parameter for the force distribution over height.

From the first analysis it can be concluded that:

- the wave forces rise very fast, but no impulse peak is visible

- wave forces on a wall oriented 45 degrees to the wave direction result in a force that is a factor 2 smaller than perpendicular wave attack

- the wave force above the flow depth is negligible

The overall conclusions from this research will be published in Doorslaer et al., 2011.

\section{ACKNOWLEDGMENTS}

The Belgian tests were issued by Flanders Hydraulics Research and the Coastal Division, both of Authority of Flanders, Ministry of Transport and Public Works.

\section{REFERENCES}

EurOtop-Manual. 2007. European Overtopping Manual, www.overtopping-manual.com. Eds. Pullen, T., Allsop, N.W.H., Bruce, T., Kortenhaus, A, Schüttrumpf, H., Van der Meer, J.W., Heide. 
Mertens, T.; De Wolf, P.; Verwaest, T.; Trouw, K.; De Nocker, L.; Couderé, K. 2008. An integrated master plan for Flanders future coastal safety. Proceedings International Conference on Coastal Engineering, ICCE 2008 Hamburg, Germany.

Steendam, G.J., J.W. van der Meer, B. Hardeman and A. van Hoven, Destructive wave overtopping tests on grass covered landward slopes of dikes and transitions to berms, Proceedings International Conference on Coastal Engineering, ICCE 2010 Shanghai, China.

Steendam, G.J., J.W. van der Meer, G. de Raat, W. de Vries and J.Y. Frissel. 2008. Influence of Management and Maintenance on erosive impact of wave overtopping on grass covered slopes of dikes. International Symposium on Floodrisk. Oxford.

Van der Meer, J.W., R. Schrijver, B. Hardeman, A. van Hoven, H. Verheij and G.J. Steendam. 2009. Guidance on erosion resistance of inner slopes of dikes from three years of testing with the Wave Overtopping Simulator. Proc. ICE, Breakwaters, Marine Structures an Coastlines. Edinburgh.

Van der Meer, J.W., B. Hardeman, G.J. Steendam, H. Schüttrumpf and H. Verheij. 2010. Flow depths and velocities at crest and landward slope of a dike, in theory and with the wave overtopping simulator, Proceedings International Conference on Coastal Engineering, ICCE 2010 Shanghai, China

Van Doorslaer, K., De Rouck, J., van der Meer, J.W., Baelus, L. and Trouw, K. Full Scale Wave Impact Tests on a Vertical Wall, using the Wave Overtopping Simulator. Proceedings Coast and Ports (to be published), 2011. Perth, Australia. 


\section{KEYWORDS - CSt2011}

Abstract acceptance number: p0171:

DESTRUCTIVE WAVE OVERTOPPING TESTS ON FLEMISH DIKES

$1^{\text {st }}$ Author: Steendam, Gosse Jan

$2^{\text {nd }}$ Author: Peeters, Patrik

$3^{\text {rd }}$ Author: Van der Meer, Jentsje, W.

$4^{\text {th }}$ Author: Van Doorslaer, Koen

$5^{\text {th }}$ Author: Trouw, Koen

Coastal structures

Dikes

Erosion of Grass Cover

Hydraulic Overload

Wave Overtopping

Wave Overtopping Simulator

Wave Impact 